\title{
Eco industrial parks in Rio de Janeiro State, Brazil: a proposal for brownfield revitalization
}

\author{
L. B. Elabras Veiga \& A. Magrini \\ Energy Planning Program, COPPE, \\ Federal University of Rio de Janeiro, Brazil
}

\begin{abstract}
Abandoned industrial contaminated sites, the so called brownfields, represent a worldwide concern. Decades of neglect have left a legacy of these previous industrial areas all over Rio de Janeiro's State (RJS), Brazil, where industrial waste was and still is sometimes disposed of in the environment without proper treatment and management practices. Many of these abandoned or under-used areas are unknown and/or the presence of hazardous substances in these areas is unknown. Many others are well known; however they represent a major management problem. In fact, RJS industrial waste management and control system has a series of failures. First, despite the vast State environmental legislation, there is no state legislation regarding the management of brownfield areas. Many industries store or dispose of their waste inappropriately, contaminating and degrading the physical and social environment. In addition, the installed capacity of existent sanitary landfills is insufficient to meet the industrial sector demand. This situation prompted the need to implement in RJS a system in order to manage brownfield areas. This study has as objective to contribute to fill part of this gap by proposing an appropriate use for the reintegration of these areas after they have been restored and rehabilitated. In order to fulfil this objective, this study first presents a picture of industrial waste generation and disposal in RJS. Two brownfield areas that are going through a process of rehabilitation are presented, Cia Mercantil Ingá, a mining industry abandoned site, and Cidade dos Meninos, a chemical industry abandoned site. This way, this study proposes the implementation of Eco Industrial Parks in brownfield rehabilitated areas. The implementation of EIP seems to represent a solution for the revitalization and occupancy of these areas from the economic, social and environmental perspectives contributing to attract new business to the locality and for the creation of healthy communities.
\end{abstract}

Keywords: brownfield revitalization, eco industrial parks, industrial waste, contaminated areas, Rio de Janeiro state. 


\section{Introduction}

From a mainly corrective focus in the 1970s, Brazil's environmental initiatives switched to a more preventive approach in the 1980s, only becoming what can be called an integrated policy from the 1990s [1]. Important institutional advances were Law 6938/1981, (for Brazilian legislation, the number after the slash mark indicates the year of enactment or issuance), which established the National Environmental Policy (Política Nacional de Meio Ambiente - PNMA). This integrative approach was based on the incorporation of the concept of sustainable development, both at the public policy level and at the strategy of firms and productive sectors. These sectors began to respond to environmental questions not only from purely cost considerations, but also as an area of market opportunity [2]. Moreover, a large number of Brazilian companies began to obtain certification according to the ISO 14,000 standard [2], the international benchmark that supports organizations in implementing or improving environmental management systems.

From the nineties onward, integrated environmental management and planning became consolidated through initiatives that: (i) strengthened the local and global components of action in the environmental field; (ii) reinforced the aspects of participation and negotiation among the actors involved; (iii) increased the use of economic instruments; and (iv) integrated the command and control instruments established by the PNMA (water quality standards, environmental licensing and zoning, conservation units and environmental education).

Brazil does not yet have a national policy on solid wastes, even though the problem of their improper disposal is one of the country's most pressing [3]. Like in most other Brazilian states, in Rio de Janeiro information on the amounts and types of industrial wastes generated and their disposal is sketchy. They are often disposed of without any treatment or control, resulting in extensive soil and groundwater contamination, rendering some sites unusable [3]. The lack of information makes it hard to inventory these areas to plan remedial actions. Some of these contaminated areas have become urban wastelands, while others are irregularly occupied by low-income people who are unaware of the contamination and the associated risks.

Despite having an extensive body of environmental legislation, the state of Rio de Janeiro does not have any specific legislation on management of contaminated areas. In the federal sphere, regulations on the matter were only issued in December 2009. Despite this lack of a legal or regulatory framework in the state, efforts are being made to monitor and control solid waste disposal and to remediate contaminated areas to allow their reintegration or safe occupation.

In this paper we first present an overview of industrial waste generation and disposal in Rio de Janeiro state. We then describe two brownfield areas that are undergoing rehabilitation, an area formerly occupied by Cia Mercantil Ingá, a mining company, and Cidade dos Meninos (Boys Town), an abandoned chemical plant site that the state government allowed to be occupied by a lowincome community because it was initially unaware of the contamination. 
Finally, we propose the implementation of eco industrial parks in reclaimed brownfield sites as a means to reintegrate these areas in the urban network.

\section{An overview of industrial waste generation and disposal in Rio de Janeiro sate}

The continuous growth of population, growth in the global demand for materials, urbanization, technological development and consumption pattern changes resulted in an increase in the amounts of byproducts and waste generated and disposed of by the industrial, residential and other sectors in the environment without proper treatment and management [4].

In Brazil the quantity, characterization and disposal of industrial wastes are difficult to identify. The sources of data are sparse and often conflicting and/or inconsistent. The public authorities in some states, such as Acre, Amapá, Ceará, Goias, Minas Gerias, Pernambuco and Rio Grande do Sul, have been conducting inventories, but this is far from the norm nationwide. Some companies that specialized in waste treatment and disposal have also been performing limited inventories.

In 2008, the Brazilian Association of Public Sanitation and Special Waste Companies (ABRELPE) released the report entitled "Panorama of Solid Waste in Brazil". This report made some remarks regarding industrial waste management in Brazil [5]:

- The extension of environmental damages and hazards caused by industrial solid waste is alarming.

- The industrial solid waste segment is still suffering from the lack of frequent, consistent and reliable data with national coverage.

- Most of industrial waste is being stored or disposed off inappropriately contaminating many sites.

- Legislation to support waste management is weak and the waste management infrastructure is still underdeveloped.

- The absence of proper integrated waste management practices has contributed to severe environmental damage and social distress.

In the state of Rio de Janeiro, in 2009 the State Environmental Institute (Instituto Estadual do Ambiente - INEA) conducted a survey of the generation of industrial waste in the state based on data supplied by industries themselves. According to this study, in 2008 industries in the state generated over 12 million tonnes (metric tons) of wastes, of which nearly 670 thousand tonnes were classified as hazardous and the rest as not hazardous [6]. Some sources, however, indicate these figures are underestimated [3], and that there is a need for a more precise inventory. Table 1 shows the data presented in the survey carried out by INEA. 
Table 1: $\quad$ Waste generation in RJS.

\begin{tabular}{|l|c|c|}
\hline \multicolumn{1}{|c|}{$\begin{array}{c}\text { Solid Industrial Waste } \\
\text { Classification }\end{array}$} & $\begin{array}{c}\text { Industrial Waste } \\
\text { Generation } \\
\text { (tonnes/year) }\end{array}$ & $\begin{array}{c}\text { Percentage } \\
\text { (\%) }\end{array}$ \\
\hline Hazardous Waste & 666,832 & 5.51 \\
\hline Non-Hazardous Waste (Class IIA) & $8,831,706$ & 73.05 \\
\hline Non-Hazardous Waste (Class IIB) & $2,591,202$ & 21.43 \\
\hline Total & $\mathbf{1 2 , 0 8 9 , 7 4 0}$ & $\mathbf{1 0 0 \%}$ \\
\hline
\end{tabular}

Source: [6]

${ }^{1}$ NBR Standard 10004 of 2004 classifies solid wastes according to their level of danger, as follows: Class I - Hazardous wastes; Class IIA - Non-inert wastes; and Class IIB - Inert wastes.

Table 2: Private firms engaged in industrial waste treatment in Rio de Janeiro State.

\begin{tabular}{|l|c|}
\hline Industrial Waste Treatment & Private Firms \\
\hline Sanitary landfill, Class I & Tribel \\
\hline Sanitary landfill, Class IIA & CTR Nova, Iguaçú, Dois Arcos \\
\hline Blending units for co-processing & Tribel, Plastimassa, Essencis \\
\hline $\begin{array}{l}\text { Cement manufacturers licensed for co- } \\
\text { processing }\end{array}$ & Holsim, Lafarge, Votorantim \\
\hline Incinerator & Tribel, Servatis, Econchamas \\
\hline
\end{tabular}

Source: [5]

Knowledge of the amount and type of industrial wastes received and treated by specialized private firms is essential to have an idea of the portion of these wastes that are being properly handled and disposed of and to allow adequate environmental control. With respect to disposal of solid industrial waste in Rio de Janeiro, the Brazilian Association of Public Sanitation and Special Waste Companies (ABRELPE) [5] surveyed the private companies engaged in this activity. These are shown in Table 2.

The lack of waste treatment and disposal facilities in Rio de Janeiro, as shown in Table 2, is even more serious due to the change in ownership of the company Tribel. The incinerator, co-processing unit and other assets of Tribel, a subsidiary of Bayer, were recently acquired by the environmental services firm Haztec, which reported it intends to operate them at the same location. The class I sanitary landfill is practically out of operation, only being used by the company itself.

Rio de Janeiro has a population of over 16 million people, living in 92 municipalities [7]. A comparison of these figures, along with the industrial waste generation numbers in Table 1, against the number of treatment and disposal units shown in Table 2 reveals how serious the lack of these units is in the state. Unfortunately, no public information is available on the quantity of waste treated at each of these units. 


\section{Brownfield areas in Rio de Janeiro state}

The deficient installed capacity for treatment and disposal of industrial waste in Rio de Janeiro makes the state vulnerable the further increases in the number and extent of contaminated areas, and the lack of comprehensive and accurate data hinders public and private efforts to remedy the problem. As previously stated, many of the abandoned or under-used areas either become urban wastelands or are invaded by poor people looking for space to build shanties, usually with no knowledge of the health risks. In both cases, this situation presents a major management problem for the public authorities [9].

Two brownfield sites in the state are particularly worth mentioning: the site of the former Companhia Industrial e Mercantil Ingá, located in the municipality of Itaguaí on Sepetiba Bay, which contains high levels of heavy metals (cadmium, chromium, zinc and lead), and Cidade dos Meninos, in the municipality of Duque de Caxias, which contains high levels of hexachlorocyclohexane ( $\mathrm{HCH})$. These are two critical areas that need remediation strategies by the government. In the next two subsections we examine each of these in more detail.

\subsection{Cia mercantil ingá case}

Companhia Mercantil Ingá, a company engaged in ore processing for production of zinc located in the municipality of Itaguaí on Sepetiba Bay in the southern part of Rio de Janeiro, started operating in 1962 [9]. The first complaints by nearby residents were raised in 1965, accusing the company of releasing its effluents into nearby marshlands, killing native species in the region, not to mention the solid wastes generated.

In the 1980s the company built a "containment dike around the perimeter of the waste disposal area" [10]. Nevertheless, in 1996 a serious accident occurred in which 50 million liters of water containing toxic wastes leaked into Sepetiba Bay [10]. The company went out of business in 1998, leaving behind $390 \mathrm{mil} \mathrm{m}^{3}$ of liquid effluents in a basin covering 260 thousand $\mathrm{m}^{2}$ [9]. Part of these effluents leaked again, contaminating the bay's waters with more heavy metals such as zinc, cadmium, chromium and lead [9].

In response to these ecological disasters, the State Environmental Secretariat and a group from Rio de Janeiro State University joined forces to draw up plans to clean up the area. In 2009 the state government made an agreement with mining company Usiminas to start the decontamination process [6]. Under the agreement formed, Usiminas is responsible for envelopment of the toxic wastes and decontamination of the site. According to information posted at the website of INEA [6], this process will definitively prevent further contamination of the soil and water.

This is an important effort, particularly due to the plans to build a highway called Arco Metropolitano, part of which will go around the Port of Sepetiba, near the former factory site. This will make the area more valuable and attract new industrial activities [6]. 


\subsection{Cidade dos meninos case (Boys Town)}

The region known as Cidade dos Meninos ("Boys Town") is located in the municipality of Duque de Caxias, on an area of about 19.4 million $\mathrm{m} 2$ [9]. The name comes from the fact it was the location of a boarding school and other training facilities for disadvantaged boys, founded in 1943 by the federal government. In 1949, the federal government decided to establish a factory on part of the grounds to make the organochloride compound $\mathrm{HCH}$ (hexachlorocyclohexane) along with other pesticides, to be used in government anti-malaria campaigns. However, in 1955, due to various problems the production of $\mathrm{HCH}$ became uneconomic, and from then on the plant's activities were gradually scaled back until it was finally closed in 1961 [9].

However, the shut-down was done without following even minimal safety precautions to avoid contamination. In 1989, 28 long years later, the state environmental agency finally conducted an investigation, finding an open-air storage area covering some 13 thousand $\mathrm{m}^{2}$ containing huge amounts (the exact amount is in dispute) of $\mathrm{HCH}$ in direct contact with the soil and leaching down to the water table. At that time the training facilities were gradually being phased out, but many families were living in the area, some newcomers and others the families of former and current school employees. In 1995 the Ministry of Health (federal) conducted a study and found $\mathrm{HCH}$ concentrations in blood samples from residents 65 times higher than found in a control group [9]. This finally prompted the Health Ministry to undertake efforts to decontaminate the area. However, the procedure followed to decontaminate the area instead contributed to aggravate the situation. The focus area of the cleanup spread from $2,000 \mathrm{~m}^{2}$ to $33,000 \mathrm{~m}^{2}$, a more than sixteen-fold increase [9].

In 2000 and 2001 the Health Ministry took some further measures: the main contaminated area was fenced off and warning signs were posted; the families living in the focus area were removed; secondary focus areas were identified; part of the contaminated material was removed; 40 tonnes of $\mathrm{HCH}$ was incinerated; and further tests were run to determine the air contamination [9]. Nevertheless, these federal efforts were not enough and the area remained seriously contaminated. Only in 2007 did the State Environmental Secretariat (SEA-RJ) start its own decontamination process [6]. This case attracted global publicity for its seriousness and decades of irresponsible policies. Currently the SEA is trying to define a use for the reclaimed area [6].

\section{Methodology for eco industrial parks implementation in revitalized brownfield areas}

In recent years, attention to EIP development has grown among governments, academia and industries in many countries, particularly in the United States of America (USA), where the concept was developed in the beginning of the 90's by the United States Environmental Protection Agency (US-EPA) [11]. The major force behind the EIP concept is that it yields better economic, environmental and social results than do industries acting independently. 
One of the Industrial Ecology (IE) tools, an eco-industrial park is a community of manufacturing and service businesses seeking enhanced environmental and economic performance through collaboration in the management of waste, energy, water, and raw materials. The goal of an EIP is to improve the economic performance of the participating companies while minimizing their environmental impact. Components of this approach include pollution prevention, reduction, reuse, recycling of by-products and waste (3 R's), inter-company partnering, green design of park infrastructure and plants, and energy/water efficiency. Compared to a traditional industrial park, the emphasis of an EIP is on material, energy, and water efficiency as it reduces both pollution and demands for natural resources typically used as raw materials. In short, the waste of one business becomes the resource of another [11-14].

In North America, more specifically in the USA [11, 15] and in Canada [15, 16] there are many EIPs projects being implemented and many already operating. In the USA, with the support and financing of the US-EPA, that developed a program entitled "EPA's brownfields Program", many EIPs are being developed in brownfield revitalized areas [17, 18]. As examples it is worth to mention: Oak Point Eco-Industrial Park, New York, Devens EIP, Massachusetts, Knoxville EIP, Tennessee, Fairfield EIP, Maryland, Front Royal EIP, Virginia, Plattsburgh EIP, Nova York, Volunteer EIP, Tennese, and many others $[15,19,20]$. In this country EIPs are being considered a possible way to overcome environmental distress and at the same time to improve industrial and community economic and social welfare and development.

EIP development on a brownfield site after the site has been restored and rehabilitated and made ready for development does not refer solely to removing potentially hazardous contamination and getting a new business located on the site, it look for finding an approach to brownfield reuse that offers the most significant long-term benefits to the local community-using resources efficiently and reducing waste while encouraging local economic growth [18].

As Gertler [21] points out, the reasoning in choosing a brownfield site for developing an EIP instead of a greenfield site is simple: "why degrade a pristine (or at least undeveloped) ecosystem when an already disturbed one is available? This is a choice with regard to EIP development in Chattanooga, Tenessee".

Regarding EIP development, Schlarb [12] explains: "There is no one size fits all answer for eco industrial development. This is a flexible, creative approach to industrial and economic development". Even though EIP planning needs to be flexible, the specific characteristics of the area in question to be revitalized should be considered, particularly regarding soil and surface hydrology analysis after remediation to check the feasibility of development and any constraints, along with other important factors such as demand from prospective users and the local community. According to Peck [13], even a flexible process must follow some methodology to serve as a guideline, specifying the minimum elements necessary to implement an EIP. This method should be equally followed by the decision-makers and other actors involved in the steps of the process so that they do not work at cross-purposes. Figure 1 presents a flow chart summarizing the steps suggested here to implement an EIP at a brownfield site [8]. 


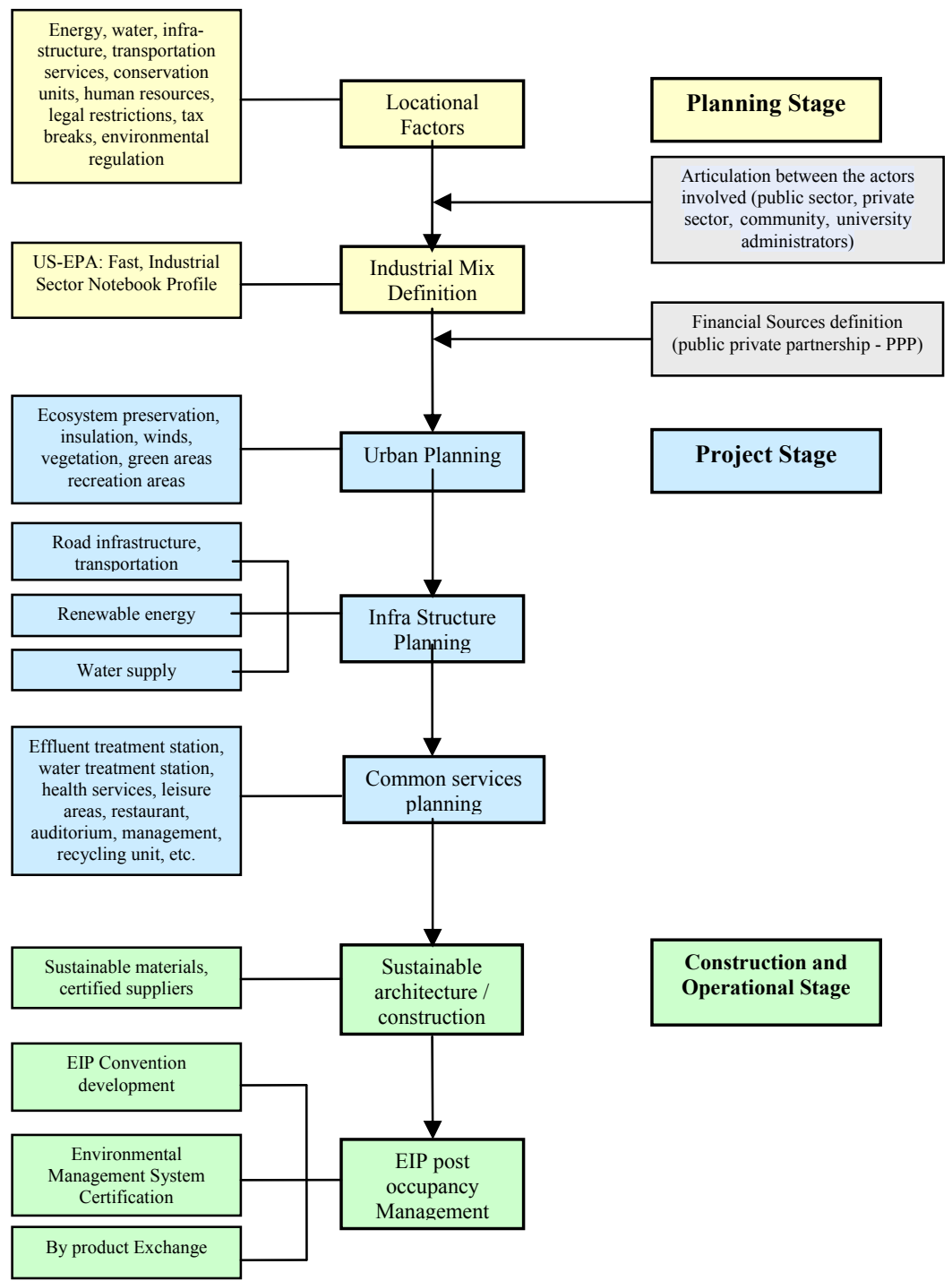

Figure 1: $\quad$ EIP suggested planning stages.

Some of the main elements of the planning, design, construction and operation of an EIP, according to the studies conducted by Lowe [14], Schlarb [12], Desrochers [22] and Rosenthal et al. [11], are: identification of location factors; articulation of the actors involved (e.g., through community workshop meetings to help inform the design and components of the feasibility analysis); selection of the mix of industries; definition of the financing sources; layout of the public services and infrastructure (roads, transportation, electricity, water, effluent treatment, etc.), taking maximum advantage of existing infrastructure; 
definition of the shared areas and services; construction of sustainable buildings and installations; and occupation and management of the EIP. It should be designed specifically for the particular use at the site [8] and the revitalization and occupancy of the area should provide significant business and employment opportunities for the local workforce.

\section{Conclusion}

As demonstrated along this paper, brownfield revitalization and occupancy provides communities with the tools to reduce environmental and health risks, reuse abandoned areas, take advantage of existing infrastructure, attract new businesses and jobs, and reduce the pressure to develop industrial districts in Greenfield sites.

In RJS, the existence of brownfield areas, as Cia Mercantil Inga and Cidade dos Meninos, prompted to the need to implement a system in order to manage these previously developed areas, contaminated by the legacy of previous industrial uses, reintegrating them in the urban network after they have been restored and rehabilitated. As it is happening in the USA, EIP development is a possible strategy. However, public policies are needed to guide this process.

After a studying EIPs development for a long time, this author is confident that EIPs is a viable alternative to brownfield's revitalization and occupancy. EIPs are designed to promote a win-win situation; that is, to bolster economic development while protecting the environment. However, EIPs development in an area where industries might incur in liability, such as in brownfields sites, cannot be successful without the economic and political support and incentive from government. It requires partnership and cooperation among the government, developers, community, university and industry to make the whole process work. As with any strategy for development, a quantitative analysis of the economic benefits to the community and to the municipality itself should be carried out. As it is already happening in the USA, RJS will recognize that the economic and environmental benefits of EIP development outweigh the costs, making it a sustainable land use for brownfield abandoned sites.

\section{Acknowledgement}

We thank FAPERJ Foundation for the financial support.

\section{References}

[1] Magrini, A., Muylaert, M. S. \& Montez, E. M., Environmental Conditionings and Industrial Zoning in the Metropolitan Area of Rio de Janeiro. In: Brebbia, C.A., Ferrante, A., Rodriguez, M. \& Terra, B. (Org.). The Sustainable City-Urban Regeneration and Sustainability. Southampton, v. 01, pp. 427-435, 2000. 
[2] Magrini, A., Política e Gestão Ambiental: Conceitos e Instrumentos, In: Magrini, A. \& Santos, M.A. (Org.). Gestão Ambiental de Bacias Hidrográficas, Rio de Janeiro: COPPE/UFRJ, pp. 9-19,.2001.

[3] Magrini, A., Elabras Veiga, Lilian B., Morais, V.R., "Estudo de Sinergias de Resíduos da CTR ESSENCIS de Paracambi/RJ”, COPPE/UFRJ, 2010.

[4] Elabras Veiga, L.B., Magrini , A., Szklo, A.S., "Eco Industrial Parks: a tool towards the reduction, reuse and recycling of by-products and wastes - Case Study in Paracambi EIP, Rio de Janeiro State", Fourth International Conference on Waste Management and the Environment, Spain, WIT Press, 922pp. pp. 395-404, 2008.

[5] Associação Brasileira das Empresas de Limpeza Pública e Resíduos Especiais (ABRELPE). Panorama de Resíduos Sólidos no Brasil, São Paulo, Brasil, 2008.

[6] Instituto Estadual do Ambiente (INEA), available at www.inea.rj.gov.br, access in April 2010.

[7] Instituto Brasileiro de Geografia e Estatistica (IBGE), available at www.ibge.gov.br, acess in Abril 2010.

[8] Elabras Veiga, Lilian B., "Diretrizes para o Planejamento de Parques Industriais Ecológicos: uma proposta para o PIE de Paracambi”, PhD. Thesis, Programa Planejamento Energético, PPE/COPPE/UFRJ, RJ, 2007.

[9] Gomes da Silva, R.F., "Gestão de Áreas Contaminadas e Conflitos Ambientais: o Caso da Cidade dos Meninos", M.Sc. Dissertation, Programa Planejamento Energético, PPE/COPPE/UFRJ, RJ, 2007.

[10] PINTO, Luciana Madeira de Oliveira. Implicações da Contaminação por Metais Pesados no Meio Ambiente da Baía de Sepetiba e Entorno: O Caso da Cia. Mercantil Ingá. Master Dissertation Universidade Federal Fluminense. Niterói, RJ, 2005.

[11] Rosenthal, E., Bell, M. \& Mcgalliard, T. N., Designing Eco Industrial Parks: the North America Experience, WEI, Cornell University, 1998. Available at: www.cfe.cornell.edu/wei/, access in October 2004.

[12] Schlarb, M., "Eco Industrial Development: a strategy for building sustainable communities", U. S. Economic Development Administration, Work and Environment Initiative, Cornell University, 2001.

[13] PECK, S., "When is an Eco-Industrial park not an Eco- Industrial Park", Journal of Industrial Ecology, V. 5, n. ${ }^{\circ}$ 3, pp. 3-5, MIT Press, 2002.

[14] Lowe, E., "Handbook for Development of Eco-Industrial Parks", disponível em: http://indigodev.com, 2001, access in October 2006.

[15] University of Hull, North American Sites: http://www.hull.ac.uk/geog//EcoInd/html, access in April 2010

[16] Canadian Eco Industrial Network (CEIN), http://www.cein.ca/cein/projects.html, access in November 2007.

[17] US-EPA, "Characteristics of Sustainable brownfield's Projects", Task 1 Report, July, 1998.

[18] US-EPA, "Sustainable Redevelopment of brownfields-Fostering Economic Development and Protecting the Environment, EPA 500-F-03031, available at: www.epa.gov/ brownfields/, 2003 
[19] Sustainable South Bronx \& Green Worker Cooperatives, "The Oak Point Eco-Industrial Park: A Sustainable Economic Development Proposal for the South Bronx", New York, USA, 2007.

[20] Potts Carr, A.J., "Choctaw Eco-Industrial Park: an ecological approach to industrial land-use planning and design", Landscape and Urban Planning V.42, pp. $239 \pm 257,1998$

[21] Gertler, N. Industrial Ecosystems: Developing Sustainable Industrial Structures, M. Sc. Dissertation, Department of Civil and Environmental Engineering, MIT, USA, 1995.

[22] DESROCHERS, P., "Eco-Industrial Parks: the case of private planning", The Independent Review, v. 5, n 3, pp. 345-371, 2001. 